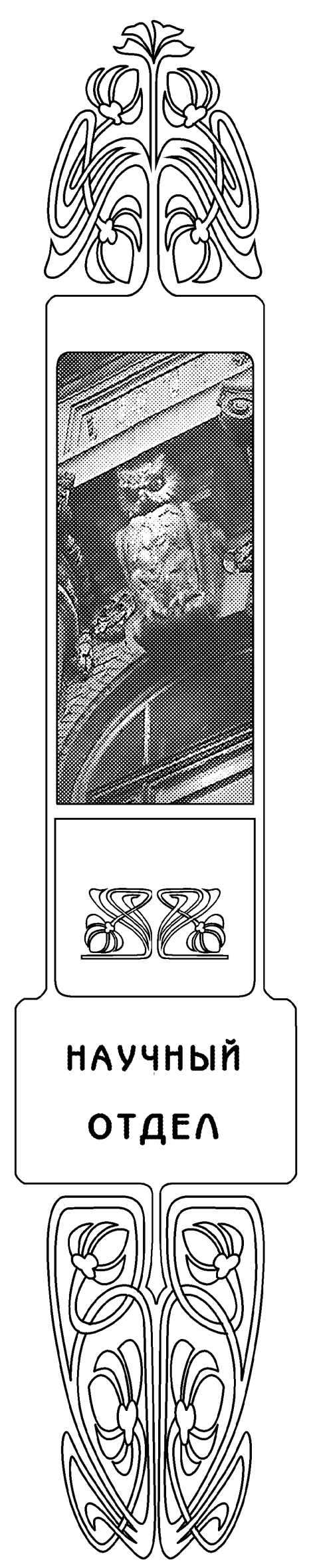

\title{
ГЕОЛОГИЯ
}

УДК [56:551.736](470)

\section{МАССОВОЕ ВЫМИРАНИЕ КОНЦА ПЕРМИ: СОБЫТИЯ НА ТЕРРИТОРИИ РОССИИ}

\author{
М. Бентон \\ Департамент Наук о Земле, \\ Бристольский университет, Великобритания \\ E-mail: mike.Benton@bristol.ac.uk(M.Benton)
}

\begin{abstract}
Массовое вымирание на суше и море 251 млн лет назад на границе перми и триаса было, несомненно, величайшим за всю историю Земли. Седиментологические и геохимические данные показывают глобальное увеличение температуры, что привело к значительному недостатку океанического кислорода, интенсивной эрозии отложений, особенно почв.

Указанные феномены могли быть вызваны колоссальными извержениями сибирских траппов, которые продуцировали двуокись углерода, что вызвало парниковый эффект, а также было причиной выпадения кислотных дождей. Эти дожди уничтожали растительный покров, что, в свою очередь, приводило к полной эрозии почвы. Наша полевая работа в России за прошлое десятилетие подтвердила интенсивную эрозию на границе перми и триаса, коллапс природных экосистем и их медленное восстановление после этого.
\end{abstract}

Ключевые слова: массовое вымирание, пермь-триас, климатические изменения, «парниковый эффект», экспедиции, Россия

\section{The End-Permian Mass Extinction Events on Land in Russia}

\section{Benton}

The mass extinction of life in the sea and on land 251 million years ago, at the Permian-Triassic boundary, was undoubtedly the largest mass extinction of all time. Sedimentological and geochemical evidence shows that global temperatures rose, that there was extensive oceanic anoxia, and that there was massive erosion of sediment, especially soils, from the land. These phenomena might have been a consequence of the massive eruptions of the Siberian Traps, which produced carbon dioxide, and greenhouse gas, as well as acid rain, which killed plants and led to stripping of soils. Our field work in Russia over the past decade, has shown evidence for massive erosion at the boundary, and for the nature of ecosystems collapse and slow recovery after the event.

Key words: mass extinctions, Permian-Traissic, climatic changes, «greenhouse effect», expeditions, Russia

\section{Введение}

Я много лет интересовался массовыми вымираниями и их влиянием на жизнь, в частности, позвоночных животных на суше. Несколько лет назад я ознакомился с учебником «Палеонтология позвоночных и эволюция» Боба Кэрролла [1]. Он пишет, что «большинство драматических вымираний в морской обстановке занимает конец перми, уничтожив 95\% беспозвоночных видов и более чем половину семейств. Удивительно, что не было большого вымирания наземных и водных позвоночных» $[1,123]$.

Неправдоподобно выглядело, что массовое вымирание, зафиксированное отдельно в морском бассейне, имело ограниченный эффект на суше. Я был заинтригован и попытался установить, почему эти данные такие противоречивые.

Массовое вымирание конца перми, или событие на границе перми и триаса, произошедшее 251 млн лет назад, было величайшей потерей $90-95 \%$ всех видов на суше и море.

* Перевод Г.И. Твердохлебовой. 
Знания об этом событии сильно изменились с 1990 г. Ранее большее внимание было сфокусировано на событиях на границе мел-палеоген (65 млн лет назад). Было ясно, что в этом случае Земля стала горячей благодаря астероиду, который привел к катастрофическим изменениям среды, выразившимся в вымирании 50\% видов. Удивительно, что даже более значительное событие на границе перми и триаса было окутано тайной.

Erwin [2, 3] представил обзор взглядов на пермо-триасовые события в двух книгах и ряде статей. Он отразил их неопределенность, заключавшуюся в установлении не только масштабов произошедшего вымирания, но и времени событий и возможных их причин. С появлением новых фактов положение дел изменилось. Эрвин указывает продолжительность пермо-триасовых событий до 8 млн лет. В настоящее время известно, что они занимали менее 1 млн лет. Он отметил общие различия фауны в море до и после вымирания. Сейчас имеются полевые изучения в нескольких частях мира с обеспечением до миллиметровой точности. Эрвин говорит о комбинации возможных спусковых механизмов среды, связанных частично с длительным расширением Земли, взрывным освобождением газового гидрата, а также с выбросами вулканического материала, моделью которых являются сибирские базальты.

Эрвин немного касается природы событий на суше, где появляются значительные свидетельства смыва почв и как следствие вымирания большинства видов флоры, быстрого выноса растительного детрита в океан, что привело к коллапсу сложных экосистем. Изменение взглядов на пермо-триасовое вымирание отражено в недавних статьях $[4,5]$.

В этой статье я делаю обзор работы, которую мы проводили еще в начале 1990-х гг, связанную с пониманием событий пермо-триаса. Я также немного расскажу о постановке вопроса и о забавных событиях во время полевых работ в России.

\section{Первые поездки в Россию}

Мы впервые посетили Россию в 1993 г. как участники совместной программы фундаментальных исследований Королевского общества (Лондон) и Российской АН (Москва). В эти главные дни сразу после перестройки была огромная политическая воля заняться Россией и помочь ей освободиться от советских времен. Королевское общество открыло офис в Москве, чтобы помочь британским ученым в поездках в Россию и снабжать билетами и деньгами российских ученых для визитов в Англию.

Во время нашего первого визита я и мой коллега Гленн Сторрс встретились с российскими палеонтологами и посмотрели замечательные коллекции в Музее Палеонтологического института РАН в Москве. Мы также участвовали в полевых работах, чтобы увидеть местонахождение раннего триаса на р. Волге около г. Рыбинска, где были найдены отлично сохранившиеся черепа и скелеты амфибий, переживших массовое вымирание.

В наш второй визит, в 1994 г., Гленн и я провели короткое время в Москве, но главным нашим желанием была поездка в поле, чтобы увидеть пермо-триас из первых рук. Мы поехали поездом до г. Оренбурга к подножию Уральских гор, совершив 36-часовое путешествие на восток от Москвы. Наши коллеги из Москвы М. Шишкин и А. Сенников сопровождали нас в поезде, мы встретились с полевыми геологами В. Твердохлебовым и В. Очевым в Оренбурге. Эти два ученых поделились обширными знаниями о породах и фоссилиях в Предуралье. В. Очев был выдающимся палеонтологом. Он изучал ископаемых амфибий и рептилий пермо-триаса Урала с конца 1950 г. и опубликовал много статей с их описанием. В. Твердохлебов - полевой геолог, специалист по седиментологии и интерпретации древних обстановок и климата. Он работал в геологической службе СССР, затем России, составляя геологические карты и карты поисков полезных ископаемых.

Экспедиция 1994 г. была более 2 недель. За это время мы увидели дюжину местонахождений поздней перми и раннего триаса, во многих из которых были открыты ископаемые амфибии и рептилии. Было сравнительно легко найти зубы и кости в русловых отложениях, особенно в раннем триасе, но более основательные находки были редки, так как фоссилии могли быть найдены только в оврагах, разрезающих степные просторы, эродированные медленными темпами. В. Очев и его коллеги нашли много прекрасных образцов в 1950-60 гг., применяя бульдозер, который успешно обнажал обширные впадины в земле, где имелись одиночные скелеты больших рептилий, иногда целое поле скелетов, тесно сочлененных.

Мы планировали большую экспедицию в июле 1995 г. с четкими целями. Г. Сторрс и я приехали вместе с другими коллегами, специализировавшимися на полевой седиментологии (Э. Ньювелл) или ископаемых рептилиях (П. Спенсер, Д. Говер, Д. Патридж). Мы разбились на две команды и смогли сделать полигоны седиментационных последовательностей. Мы провели ревизию мест, где были в 1994 г., чтобы это увидели все члены экспедиции.

Результатом сбора информации явилась публикация о главных изменениях на границе перми и триаса [6] и позже о массовом вымирании в пермотриасе российских амфибий [7]. Я вернусь к этим темам ниже, более полный отчет о наших ранних российских экспедициях можно найти в [4].

\section{Экспедиция 2004 г.}

Логистика.

Наши ранние полевые работы показали потенциал Оренбургских пермо-триасовых красноцветных отложений, и мы оценили высокий резервный фонд. Мы обратились с просьбой к Национальному 
Географическому обществу о поддержке исследования основными суммами на полевой сезон (месяц или около того), так как в дальнейшем деньги от Королевского общества пошли на обмен визитами между Бристолем и Саратовом. В июле 2004 г. команда из 5 человек - Ричард Твитчетт, ученый, работающий над докторской диссертацией в Токио, Энди Ньювелл, бывший студент из Бристоля, который был седиментологом в 1995 г., а сейчас - геолог Британской Геологической службы, Синди Лу, датский палеоботаник и палинолог, которая работала с Твитчеттом в Гренландии на границе перми и триаса, мой сын Дональд, 14 лет и я прибыли для проведения полевых работ в Россию. Нашим сотрудником, как всегда, был В. Твердохлебов - глава экспедиции и М. Сурков, наш палеонтологический сотрудник и переводчик, также два студента, водитель, повар.

Мы были в трех местах: на берегу р. Сакмары около 2 недель, затем одну неделю в Корольках около р. Елшанка на азиатской стороне Урала близ г. Соль-Илецк и, наконец, на берегу р. Ток возле г. Бузулук, между Оренбургом и Самарой. Наша цель поездки на все эти местонахождения оправдалась, мы видели много хороших разрезов на границе пермо-триаса, собрали фоссилии и образцы для изотопного анализа.

\section{Седиментационные изменения: огромный водный сток}

Из нашего лагеря на берегу Сакмары мы поехали к местонахождению знаменитой горы Самбулла для изучения границы пермо-триаса. Мы были здесь в 1995 г., но А. Ньювелл и Р. Твитчетт сделали новые седиментационные записи и отобрали карбонатные породы для изотопного анализа. Самбулла находится на расстоянии примерно 5 км от лагеря, и мы объезжали вокруг полей ферм по открытой степи. На вершине можно было обозревать большие просторы до г. Саракташа, 20 км по прямой, вдоль меандрирующей залесенной долины Сакмары, широкому притоку Урала. Гребень горы Самбулла сложен 10-метровыми хорошо сцементированными массивными конгломератами, наклоненными на $10^{\circ}$ и более на запад. Пройдя 1 км вдоль гребня, вы можете спуститься плавно с самой высокой точки к реке. Эти конгломераты отмечаются на соседней линии холмов и четко протягиваются на некотором расстоянии, образуя часть основания громадного пролювиального конуса, шириной более 20 км и протяженностью на запад до 50 км, в направлении от Уральских гор.

Наши ранние наблюдения показывают, что разрез Самбуллы ниже конгломератов состоит из повторяющихся полных циклов. Такие циклы начинаются с разнозернистых косослоистых песчаников, переходящих в алевриты и аргиллиты, и заканчиваются палеопочвами. Палеопочвы иногда связаны с растительными остатками, и они всегда замещены карбонатом. Отмечается следующая закономерность: отложения циклических озер с временными поверхностными потоками (разнозернистые песчаники) сменяются тонкозернистыми отложениями и в конце, когда озеро высыхает, образуются палеопочвы. Это, возможно, является результатом резко выраженного сезонного климата. В России имеются четкие биостратиграфические доказательства, что тонкие озерные отложения были позднепермскими по возрасту - верхняя часть татарского яруса - вятские слои. Они датируются вышележащими конгломератами нижнего триаса (вохминские), основываясь частично на данных геологического картирования, частично на находках остракод и водных тетрапод Tupilakosaurus в ассоциации русловых фаций. Эта датировка возраста, возможно, правильная, но она должна быть приведена в соответствие с другими стратиграфическими подразделениями в России и более детально сравнима с международной (морской) временной шкалой.

Newell [8] в России сделал предварительную интерпретацию доказательств главных изменений флювиального режима: в самом верху перми, близ границы с триасом, кластические осадки показывают сравнительно низкий энергетический уровень осаждения меандрирующими потоками. Выше границы осадки показывают высокий энергетический потоковый режим с отложением конгломератов, близких к Уральским горам, и грубозернистых песков на большие расстояния. В. Твердохлебов, изучавший эти грубозернистые осадки, отложившиеся в начале триаса, связывал их с возобновлением поднятия Урала. Урал поднимался первоначально в позднем карбоне и ранней перми на контакте Евразийской и Сибирской континентальных плит. Движение плит и тектоническая активность глубинной шовной зоны неоднократно возобновлялись. В. Твердохлебов [9] отметил, что грубые осадки образовывали пролювиальные конусы (alluvial fans) (рис. 1), которые изливались в западном направлении от передовых складок Урала, протяженностью от 100 до 150 км, перекрывая отложения озер и меандрирующих рек на обширной равнине Предуральского прогиба. Он идентифицировал все валуны и гальки в различных триасовых пролювиальных конусах и нашел, что такие конусы имеют собственные отличительные черты, показывающие тонкое различие источников пород из глубин Урала. Конгломератовые валуны включают обломки девонских и карбоновых известняков, часто окремнелых, метаморфических и изверженных пород.

Независимо друг от друга Р. Смит, седиментолог, работающий в Ю. Африке, и его коллега П. Уорд из Университета Сиетла пришли к сходному заключению. Замечательный разрез пермо-триаса в Карро показывает похожие седиментационные изменения от низкоэнергетического режима меандрирующих потоков в поздней перми к высокоэнергетическому режиму 
ветвящихся потоков и пролювиальным конусам выноса в раннем триасе [10]. Затем похожие сдвиги (shift) в флювиальной системе отмечены у границы пермо-триаса в Австралии [11], Индии [12] и Испании [13]. Такие изменения наблюдаются не везде: в нескольких разрезах пермо-триаса, например в Антарктике, имеются доказательства огрубления песчаников выше этой границы, но ветвящиеся потоки были и в течение поздней перми, а главное изменение - переход от песчаников с доминированием вулканических обломков в перми к песчаникам с кварцевыми обломками происходили в раннем триасе [14]. Изучение почв, в частности их химических характеристик [15], показало, что имелся почвенный эрозионный кризис, где почвы и органический материал с суши были смыты в море.

Если это был всемирный феномен, тогда локальный масштаб тектонизма не может быть причиной, но что тогда?

Возможно, были глобально масштабные поднятия с горами, воздымающимися в нескольких частях мира. Но независимого свидетельства такой глобальной активности не найдено. Вероятно, было огромное увеличение выпадения дождевых осадков во всем мире? Снова нет четкого доказательства для такого феномена, нет объяснения того, как это происходило. Скорее всего, верно предположение о редукции дождевых осадков.

Невел показывает, что главный вынос гравия около границы перми и триаса вызван внезапным увеличением размера русел, это могло быть связано с изменением климата. В настоящее время имеются веские доказательства глобальных изменений климата от субгумидного в поздней перми к одной из величайших аридизаций в раннем триасе. С ней связана редукция растительного покрова и, как следствие, увеличение скорости осадконакопления. Если растительность смыта с поверхности суши, темпы эрозии могут увеличиваться, возможно, в десять раз. Это событие вместе с другими доказательствами свидетельствует, что нормальные зеленые растения периодически уничтожались и замещались горизонтом, у границы водоемов, в котором доминировали прибрежные формы, продуцированные грибами и водорослями. Ниже этого горизонта осадочные породы содержат споры папоротников, семена высших растений, хвощей и других растений низшего, среднего и древоподобного уровней. Такие растения вскоре вернулись к прежнему уровню в раннем триасе. Но папоротникововодорослевые приграничные слои показывают драматизм нормальной растительности. Сегодня мы знаем опустошающую эрозию, за которой следует возрождение растений, например, в Бангладеш, где степень выпадения осадков и эрозия увеличиваются после заготовки леса у подножия Гималаев.

\section{Изотопы и климатические изменения}

Второй главной целью нашей экспедиции 2004 г. был отбор образцов для анализа изотопов кислорода и углерода. У границы перми и триаса наблюдается резкий сдвиг в составе изотопов кислорода в морских карбонатах, увеличение значения ? ${ }^{18} \mathrm{O}$, отвечающее глобальному возрастанию температуры на $6^{\circ}$. Климатическая модель показывает, как глобальное потепление может уменьшить океаническую циркуляцию и количество растворенного кислорода, создавая недостаток его в океане. Недостаток кислорода в морях проявляется глобально. Этот эпизод сверхпониженного содержания кислорода, приведшего к убийственным последствиям для жизни на морском дне [16], может служить частью модели восстановления событий на рубеже перми и триаса.

Углеродные изотопы очень важны для определения моделей массового вымирания на границе пермо-триаса. Геохимическое значение суммы изотопов ${ }^{13} \mathrm{C}$ и ${ }^{12} \mathrm{C}$ стабильно для известняков, окаменелых раковин и даже карбонатных палеопочв. В природе большая часть углерода - это ${ }^{12} \mathrm{C}$, с меньшей, но измеримой суммой ${ }^{13} \mathrm{C}$. Соотношение этих двух изотопов в атмосфере такое же, как на поверхности воды в океане. Во время фотосинтеза растения для продуцирования органического материала выбирают преимущественно ${ }^{12} \mathrm{C}$. Если этот органический материал захороняется, то он быстро возвращается в систему атмосфера-океан, где соотношение ${ }^{13} \mathrm{C}$ : ${ }^{12} \mathrm{C}$ сдвигается в сторону тяжелых изотопов. Этот коэффициент показывает отличие соотношения ${ }^{13} \mathrm{C}:{ }^{12} \mathrm{C}$ в тестируемом и эталонном образцах. В океанических системах во время высокой поверхностной продуктивности большое количество органического материала фиксируется на поверхности, и поверхностные воды океана становятся (относительно) обогащенными ${ }^{13} \mathrm{C}$. Мелководные карбонатные отложения выпадают из морской воды с фиксированным соотношением изотопов ${ }^{13} \mathrm{C}:{ }^{12} \mathrm{C}$ без предпочтительного выбора одного из них. Однако с течением времени из-за высокой поверхностной продуктивности в мелководных карбонатах регистрируется положительный сдвиг в? ${ }^{13} \mathrm{C}$ (в сторону тяжелых изотопов).

Пермо-триасовая граница характеризуется отрицательным сдвигом коэффициента ? ${ }^{13} \mathrm{C}$, который регистрируется в карбонатных отложениях во всех геологических разрезах в различных регионах, включая континентальные [17].

На поверхности Земли предполагается уменьшение биопродуктивности и темпа захоронения органического материала. Однако при детальном рассмотрении картина этого процесса представляется более сложной. Здесь наблюдается начальный короткий отчетливый отрицательный сдвиг в ? ${ }^{13} \mathrm{C}$, что почти синхронно с естественным завершением горизонта. Значения отрицательных колебаний варьируют в различных разрезах, но 
обычно они находятся в пределах 4-6\%. В большинстве разрезов наиболее мощные обратные колебания наблюдаются в конце шкалы. Однако значения коэффициентов ${ }^{13} \mathrm{C}$ никогда не изменяются до полного угасания, остаются минимальные значения около 0,5-1,5\%. Эту сравнительно маленькую разницу можно объяснить низкой продуктивностью вследствие угасания биоты. Резкие первоначальные колебания нуждаются в объяснении.

Подсчеты показывают, что сумма отрицательных изменений в 4-6\% является слишком большой для того, чтобы можно было считать недостаток биологической продуктивности единственной причиной вымираний [2]. Для этого необходимо поступление легких изотопов углерода в систему океан-атмосфера.

$\mathrm{CO}_{2}$ как обязательный компонент выбрасывается в систему атмосфера-океан с вулканическими газами, а показатель ? ${ }^{13} \mathrm{C}$ составляет $5 \%$. Но подсчет показал, что даже выход газов сибирских траппов не может быть причиной фиксируемого сдвига ? ${ }^{13} \mathrm{C}$. Даже если все живое было бы убито и вся биомасса включена в осадки, это продуцировало бы 20\% изотопов, необходимых для подобного сдвига. Основным источником легких изотопов является метан, извергавшийся из газогидратного состояния, давший до $65 \%$ ? ${ }^{13} \mathrm{C}$. Если газогидраты могут испаряться (плавиться), то даже один метан может быть причиной наблюдаемого сдвига.

Авторы работы [18] анализировали экстракты изотопов С и О, выделенные из карбонатных почв и костей рептилий из разрезов формации Карро. Они показали сходство образцов с континента на границе перми и триаса в Карро с полученными ранее данными по многим морским разрезам. Но эта задача технически осложняется тем, что весь разрез перми и триаса Карро мог быть перегрет вышележащими вулканическими излияниями слоев Дракенсберг раннеюрского возраста. Весьма вероятно, что значения изотопов О и С могли быть искажены более поздним нагреванием и подвергнуты кислотному воздействию до образованного позднее диагенетического кальцита. Мы рады, что российские разрезы не метаморфизованы поздним вулканизмом и тектонической активностью. Эти карбонатные образцы значительно легче анализировать. Первоначальные результаты подтвердили ожидаемый сдвиг в изотопах О и С на границе перми и триаса. Мы ожидаем анализа более полного материала от экспедиции 2006 г. для получения окончательного заключения об атмосферных и климатических изменениях.

\section{Вымирание тетрапод в массовом пермо- триасовом вымирании. Российские фауны}

Скелеты амфибий и рептилий найдены в позднепермских породах на Южном Урале. Позднепермская фауна России (вятское сообщество) известна с Северной Двины и Южного Урала, очень богата и разнообразна. Растительноядные включают много парейазавров Scutosaurus, огромных бегемотоподобных животных, покрытых костными выростами, и больших гладкокожих дицинодонтов Dycinodon с двумя расширенными клыками на беззубой челюсти. В структуре хищников выделено 4 вида горгонопсиан, в том числе Inostrancevia, большую саблезубую рептилию, которая, вероятно, охотилась на скутозавра и дицинодонта, а также два маленьких хищника - тероцефал и цинодонт. В других местонахождениях позднепермские рептилии включают $\mathrm{Ar}$ chosaurus - однометровую стройную рыбоядную рептилию, древнейшего члена Archosauria («господствовавшие рептилии») - группа, в которую входят еще крокодилы и динозавры. Кроме этого следует упомянуть проколофонидов - небольших рептилий с треугольной формой черепа, родственных парейазаврам, но выглядивших, как толстая ящерица. Собственно, водными были три или четыре вида амфибий.

Это была богатая и комплексная экосистема с множеством животных, как в современном наземном сообществе. Существовали растительноядные, специализирующиеся на растениях различных видов, рыбоядные амфибии, насекомоядные синапсиды, хищники, питающиеся мелкими животными, и горгонопсианы - вершина хищников, питавшихся крупными растительноядными. Эти животные были уничтожены кризисом конца перми.

Амфибии и рептилии, которые пережили кризис в раннем триасе на территории России, составляли обедненное сообщество - нижневетлужское (вохминское). Существовали только умеренно размерные растительноядные листрозавры, один вид проколофонид и редкие диапсиды, питавшиеся насекомыми и мелкими рептилиями, а также рыбоядные широкоголовые амфибии.

\section{«Большая нога"}

На протяжении всей экспедиции мы были постоянно насторожены малым количеством находок ископаемых амфибий и рептилий. Изолированные зубы и дермальные пластины - это довольно обычно для русловых отложений, особенно в раннетриасовых породах, но более полный материал был редок. Наша сносная фоссильная находка была в экспедиции 1995 г., когда А. Сенников обнаружил череп проколофонида Kapes в раннетриасовых песчаниках, образец позже описал В. Новиков. Многого мы не ожидали и были удивлены находкой в овраге Корольки. Однажды, на 5-й день стоянки, Р. Твитчетт обнаружил в овраге отдельный блок, на котором выступало три радиальных, идущих от центра, отпечатка. Блок был 30 см в поперечнике. Затем, сделав шаг по дну оврага, он увидел вмятину в основании пласта песчаника. Это был небольшой 
желоб (канал), или отпечаток нагрузки, но мы решили осмотреть дальше. Мы взяли отдельный блок в лагерь и показали русским коллегам. Сначала это их не впечатлило, но они согласились поехать на место. Ричард был убежден, что два блока были с фоссилизированными следами больших животных. В. Твердохлебов поручил Саше и Эдуарду работать на песчанике, и они перевернули плиту за плитой, которые мы затем подгоняли вместе. Отпечатки были громадные, около 50 см в поперечнике. Эти тяжелые блоки были к тому же по-разному ориентированы. Но после 10 минут тяжелой работы все согласились, что обнаружены массивные настоящие отпечатки следов пятипалого животного, - было несколько пересекающихся следов, перекрещивающихся по площади вскрытия. Валентин немедленно дал название, лучшее, что могло быть, -«большая нога» («big foot»).

Замечательная находка российских и британских геологов показывает, что отпечатки следов были частью вятской зоны, в 50 м ниже границы перми и триаса. Отпечатки находились в красновато-коричневых аргиллитах, которые отлагались из взвеси в мелководном пойменном озере. Следы позднее были оставлены в основании вышележащего тонкозернистого песчаника, который отложился после плоскостного смыва. Мы обнаружили 17 отпечатков. Российские коллеги взяли лучшие образцы для коллекции музея Саратовского университета. Но кто был «big foot»?

Фоссильные следы довольно редки в поздней перми как в России, так и в Южной Африке. О первой находке в России следов маленькой рептилии мы напечатали в 1997 г. [19]. Их нашел несколько лет назад В. Твердохлебов около нашего лагеря на p. Сакмаре у Кульчумово. Сведения о второй находке больших следов парейазавров с р. Сухоны на севере России были также опубликованы [20]. Итого было всего 3 находки, которые оказались важными для установления следообразования.

Мы впервые сравнили найденные следы с другими образцами, которые были описаны из разных частей мира. Ясно, что наши следы не новой формы, но они более или менее идентифицируются с Brontopus giganteus, описанным Неуler, Lessertisseur [21] из поздней перми Франции. Это название, данное французскими авторами, говорит о том, что животное было тяжеловесным и гигантским (буквально это означает «gigantic thunder foot» - гигантская громовая нога). Отпечаток показывает, что животное стопоходящее или полустопоходящее, ступни плоские. Передние конечности имели 5 коротких толстых пальцев одинаковой длины, задние также имели 5 пальцев, но длина их уменьшается от 2-го к 5-му пальцу. Пальцы конечностей широкие и заканчивались когтями. Сзади пальцев - отпечатки подошв ног. Отпечатки передних конечностей имеют длину 230 мм и ширину 360 мм, задних конечностей - длину 175 мм и ширину 380 мм, длина шага около 1,2 м. Некоторые следы пересекаются, показывая, что «большая нога» могла ступать вперед и назад, наблюдаются четкие отметины царапин, где когти скользили в иле.

Передние и задние конечности имели по 5 пальцев, следовательно, следы принадлежали определенно рептилиям, а не амфибиям (все амфибии имели и имеют 4 пальца на передних конечностях). Среди позднепермских рептилий имеется несколько кандидатов на принадлежность следов: парейазавры, диноцефалы и дицинодонты. Из [21] было ясно, что Brontopus был парейазавром, другие авторы считали следы «пеликозавровыми». Позже предположение оказалось неверным, так как пеликозавры были низшими синапсидами (маммалеподобными рептилиями), известными из карбона и ранней и средней перми. Они вымерли около 10 млн лет, до вятского времени. Парейазавры также исключаются по положению следов «big foot». Они имели раздвинутые передние и задние пояса с локтевыми костями, расставленными в стороны, в то время как следы Brontopus показывают частичное раздвинутое положение. Возможно, это следы-маркеры, оставленые диноцефалами и дицинодонтами. Обе группы включают тех представителей, которые были достаточно большими, чтобы оставить такие же следы, как Brontopus.

Большие российские диноцефалы могли продуцировать бронтопусоразмерные отпечатки следов - Ulemosaurus и Deuterosaurus, но их скелетные остатки более древние и известны только из верхней части уржумского яруса [22]. Во всем мире диноцефалы исчезают в конце, а большинство в середине татарского отдела. Таким образом, диноцефалы исключаются из обсуждения как потенциальные следоносители из российского материала по стратиграфии. Относительно дицинодонтов можно сказать следующее: некоторые синапсиды имеют черепа размером 0,5 м (Rhachiocephalus, Aulacephalodon) известны из верхних слоев верхней перми Южной Африки [23]. Такие же гигантские дицинодонты описаны в России - дицинодонты рода Vivaxosaurus [24] имеют черепа размером 0,4 м и известны из вятского яруса. В качестве эксперимента мы сравнили кости конечностей дицинодонта с размерами «big foot» и нашли, что они более или менее подходят к следам Brontopus. Дицинодонты имели двойной способ локомоции, при которой передние конечности удерживались в прямом или полупрямом положении, а задние были в некоторой степени расставлены. Локомоция, описанная Kemp [25], сравнима с человеком, толкающим тачку: задние конечности, шагающие прямо, парасаггитальная поза и размашистые передние конечности, скребущие спереди.

Таким образом, даже если гигантские скелеты дицинодонтов неизвестны из терминальной перми России, выявленные следы «big foot» подтверждают их присутствие. Отпечатки следов 
были оставлены растительноядными размером с гиппопотама, которые скребли растительность парой массивных клыков в верхней челюсти и резали стебли роговыми краями челюсти. Отпечатки следов высокие, так что они не могли хорошо сохраниться, но они значительно дополняют знания о жизни до массового вымирания в пермо-триасе [26].

\section{Модель вымирания}

Одной из целей наших исследований является выяснение того, как изменялась жизнь при вымирании на границе перми и триаса. Мы практически лишены возможности собрать достаточное количество образцов амфибий и рептилий из российских разрезов на границе перми и триаса. Однако В. Твердохлебов имеет полное описание местонахождений тетрапод - полные скелеты или черепа, или изолированные кости - это результат 50-летней работы в Оренбуржье. Им зафиксировано 675 образцов из 289 местонахождений в пермо-триасовой толще площади от Бузулука до Саракташа, около 400 км с запада на восток и 200 км с севера на юг. Местонахождения зарегистрированы в 13 стратиграфических единицах, которые подразделяются на позднюю пермь, ранний и средний триас.

Мы впервые увидели индексированные карточки в 1995 г. и обсуждали возможность извлечения из них ценных статистических данных. В результате анализа материалов было решено опубликовать всю документацию в двух работах, одна по ранне- и среднетриасовым местонахождениям [27], другая по позднепермским местонахождениям [22]. Эти работы дают первую оценку континентальной российской пермо-триасовой системе на русском и английском языках, и мы надеемся, что они устраняют пробел в геологической литературе. До настоящего времени многие годы эталоном стратиграфической системы была формация Карру в Южной Африке, а сведения о российских отложениях и фоссилиях печатались спорадически. Наш статистический анализ показал событийную сложность вымирания. Из средней и верхней перми России известно 7 ceмейств амфибий и 15 семейств рептилий, часть из них были краткоживущими, другие проходили через значительный промежуток времени. В составе 6 средне- и позднепермских фаун было от 4 до 7 родов мелких, средних и крупных водных тетрапод («амфибионтов»), питавшихся толсто чешуйчатыми костными, реже - пресноводными акуловыми рыбами. В прибрежной растительности обитали от 5 до 8 родов наземных позвоночных (рептилий) размерами от крошечных насекомоядных до бегемоторазмерных растительноядных парейазавров и волко-медведеразмерных саблезубых горгонопсиан, питавшихся ими.

20 из 22 позднепермских семейств вымерли на границе перми и триаса или до нее, и только
2 семейства - небольшие растительноядные проколофониды и большие растительноядные дицинодонты - пережили массовое вымирание. Из 22 семейств 11 присутствуют в конце вязниковского времени - терминальной временной единицы российской перми, вымирание 9 из них соответствует семейственному уровню вымирания в $82 \%$. Это высокая цифра по сравнению с глобальным вымиранием на семейственном уровне для морских семейств - 55\%. И, конечно, показатель высокого темпа вымирания на родовом и видовом уровне.

Модель вымирания семейств и родов в России похожа на уже известные из разрезов перми и триаса других регионов, например, в Южной Африке или Южной Америке. Схема начавшегося вымирания и его проявления до границы перми и триаса имела небольшие колебания. В действительности семейства и роды показывают, по-видимому, неустойчивое поведение с повторяющимися пиками вымирания и возвращения к исходному состоянию до вымирания.

Если предположить стабильность позднепермских экосистем, то можно сделать допущение, что смена (оборот) семейств и родов была сравнительно небольшой по времени. Но, конечно, ни роды, ни виды не существовали вечно. Модельные расчеты смены (обращений) стабильных зрелых экосистем показывают, что вероятный интервал их прохождения - 10-15 млн лет.

\section{Возрождение}

Как ожидалось, раннетриасовая фауна после события на границе перми и триаса была необычной и выглядела экологически несбалансированной. В фаунах доминировали амфибии, кроме того, существовало два переживших семейства рептилий - проколофониды и дицинодонты.

В основании триаса (копанская свита, Indian) были только среднеразмерные и большие рыбоядные в реках и озерах (Tupilakosauridae, Capitasauridae, Benthosuchidae) и среднеразмерные насекомоядные (Prolacertidae, Proterosuchidae). Дицинодонты могли присутствовать, но их фоссилии известны только позже, из раннего триаса Южного Урала, а в других местах России - из самых низов триаса.

Одно из семейств (Tupilakosaurus) можно назвать «несчастным таксоном», он присутствовал короткое время, сразу после кризиса. Другие семейства копанской свиты продолжают существовать в раннем триасе. Новый таксон добавляется через 15 млн лет в среднем триасе. Среди них среднеразмерные и большие рыбоядные жили в пресной воде, среднеразмерные растительноядные и большие хищники - на суше. Ранний и средний триас характеризуется постоянным добавлением таксонов и слабой потерей существующих семейств, смена которых была менее постоянной, чем в поздней перми. 
Наши наблюдения предполагают дальнейшее медленное возрождение тетраподовой фауны в российских разрезах с экосистемами, выглядевшими несбалансированными до конца ладинского времени (15 млн лет после массового вымирания). Донгузская и букобайская экосистемы были снова полными, но небольшие рыбоядные и маленькие насекомоядные все еще отсутствовали, так же как и большие растительноядные, и специализированные хищники, питавшиеся ими. Эти промежутки, вероятно, отражали скорее неполные экосистемы и задержку развития, чем то, что экосистема достигала равновесия в низком уровне сложности ее структуры по сравнению с наблюдениями в поздней перми. Доказательством этого является то, что позднетриасовая фауна из других частей мира показывает все семейства, известные в среднетриасовой российской фауне, а также таксоны, которые заполняют экологические бреши, - разнообразные амфибии - небольшие рыбоядные, маленькие диапсиды - насекомоядные, большие дицинодонты - растительноядные и rauisuchans - большие хищники.

\section{Модели пермотриасового вымирания и возрождения}

Наши замечательные находки тетрапод в России связаны с высокоразнообразными позднепермскими экосистемами, весьма изменчивыми во времени, с постоянной сменой родового и семейственного состава. После пермотриасового кризиса, когда экосистемы были в большей степени разрушены, темп их изменчивости значительно снизился. При длительном выживании уцелевших родов и семейств восстановление их разнообразия было замедленным процессом. За интервал в 15 млн лет полное возрождение экосистем еще не произошло.

Эти контрасты убедительно подтверждаются и в других местах. Авторы работы [28] сообщают о $69 \%$ родового вымирания на границе перми и триаса в Южной Африке, оно обосновано на изучении коллекции из 225 образцов. Только 4 рода - Lystrosaurus, Tetracynodon, Moschorinus, Ictidosuchoides - пережили пермотриасовый кризис. Установлено [28], что в 37 м от границы перми и триаса 10 родов сравнимы с 13 известными заведомо ниже этой границы, что объясняется сравнительно быстрым возрождением (в сотни тысяч лет) после массового вымирания.

Конечно, важно установить, что такое «восстановление уровня» («возрождение»). Так, «возрождение» может означать просто восстановление числа видов в фаунах после вымирания, их разнообразие соответствует уровню до вымирания. В российских фаунах это было достигнуто в раннем триасе в течение гостевского и петропавловского времени, когда существовали 10 или 11 семейств, как и в вятском ярусе терминальной перми.

Более полным представляется следующее понятие о возрождении: «восстановление числа видов и их экологической роли в фаунах». В свете этого экосистемы гостевского и петропавловского времени были неполными, так как в них не все экологические ниши были заполнены - отсутствовали мелкие насекомоядные и крупные растительноядные. Они вышли на сцену в конце среднего и начале позднего триаса около 20 млн лет после пермотриасового вымирания.

Третье определение восстановления экосистем - «возрождение высоко таксонового разнообразия в глобальном масштабе». Учитывая это, можно считать, что континентальные мировые фауны позднепермской глобальной модели не восстановились до верхнего триаса - времени появления динозавров и других групп, около 20 млн лет после пермотриасового массового вымирания.

Что касается морских семейств, то глобальный период их восстановления был более длительным, протягивался в ранний мел, когда количество глобальных морских семейств возродилось до позднепермского уровня, и продолжался 125 млн лет после пермо-триасового вымирания. Установлено, что глобальное восстановление числа морских родов прерывалось в результате дополнительного массового вымирания в конце триаса.

Российские факты говорят о медленном возрождении экосистем продолжительностью более чем 20 млн лет, в то время как для Южной Африки Smith \& Botha [28] предполагают быстрое восстановление экосистем менее 1 млн лет. Расхождение имеет частично простое объяснение, оно заключается в разнице определений. В российском примере показывается полное возрождение, в Южной Африке отражено лишь восстановление разнообразия в фаунах. Наблюдаемое явное изобилие амфибий в Южной Африке и России в раннем триасе было длительным и могло отражать некоторое смещение фациальных обстановок. Пародоксально, что в то время как ранний триас был временем увеличения аридности в России [8] и Южной Африке [28], в фауне тетрапод преобладали влагоадаптированные амфибии. Смит и Бота отмечали как особый случай гибели в Карро Listrosaurus и других таксонов, вызванной засухой в обоих регионах. Повсеместная засуха должна сопровождаться редкими муссонными атмосферными осадками, которые образовывали плотные потоки и приводили к накоплению грубых речных отложений, здесь отлагались также скелеты недолго живущих амфибий, процветавших во время короткого влажного сезона.

Возможным отклонением, разделяющим два региона, является относительное изобилие небезызвестных дицинодонтов Listrosaurus в Южной Африке и их полное отсутствие в Оренбургском регионе (хотя род известен в раннем триасе других 
российских регионов [29]). Крупные растительноядные не известны в триасе Карро и России, в Южной Африке встречались среди цинодонтов насекомоядные рептилии, неизвестные в раннем и среднем триасе Оренбуржья, только редкие формы встречены в российских разрезах других регионов [30].

Отсутствие дицинодонтов и цинодонтов в раннем триасе Оренбуржья, их относительная редкость в России должны показывать палеобиогеографическую разницу между Южной Африкой и Россией. Вопрос седиментационных фаций этих регионов требует дальнейшего осмысления.

Среди других наземных групп организмов растения показывают медленное возрождение, продолжавшееся до конца среднего триаса [31]. В некоторых частях мира, включая Россию и Южную Африку, восстановление экосистем не происходило практически до конца раннего триаса; после вымирания пермской флоры плауновые Pleuromeia распространяются повсеместно. Затем хвойные стабилизировались в раннем анизии, а новые группы цикадофитов и птеридосперм появились в позднем анизии. Повсеместное возрождение флоры по времени было более равномерным по сравнению с тетраподовой фауной России, в то время как в Южной Африке возрождение тетрапод было более быстрым.

\section{Неудержимый рост парникового эффекта: модель смерти}

Наша работа в России заключается в оценке наиболее широко распространенных моделей массового пермо-триасового вымирания. Незначительное меньшинство объясняет его внеземными причинами - импактным событием того времени, свидетельства которого весьма ограничены $[4,32,33]$.

Большинство совокупных данных указывает на земные причины основной модели вымирания, состоящей из комбинации уже описанных геологических и палеонтологических факторов совместно с происшедшим в то время гигантскими проявлениями магматических процессов на территории Восточной Сибири.

В конце перми этим извержением было излито 2 млн км ${ }^{3}$ базальтовой лавы, покрывшей 1,6 млн км ${ }^{2}$ поверхности восточной России, мощность покрова составила от 400 до 3000 м. В 80-х годах впервые было высказано предположение, что массивная вулканическая активность могла быть звеном в массовом пермо-триасовом вымирании. Сибирские траппы состояли из потоков базальтов, которые более чем за тысячу лет излияния образовали толщи значительной мощности. Ранее датировка образования Сибирских траппов имела колоссальный порядок цифр от 160 до 280 млн лет с наибольшей концентрацией в пределах от 230 до 260 млн лет.
Многочисленные последние данные по новейшим радиометрическим методам дают точную дату пределов извержения порядка 600000 лет, позднейшими работами определены точно главные фазы излияния и их уточненные даты. Это может послужить ключом к датировке пепловых слоев в осадочных толщах значительно удаленного Южного Китая.

С 90-х гг. были предприняты попытки увязать многие геологические данные - содержание океанического кислорода, глобальное потепление, катастрофическое уменьшение разнообразия и изобилия жизни - с выбросами сибирских траппов для создания связной модели вымирания. Резкое снижение содержания изотопов углерода до уровня массового вымирания, вызывает драматическое возрастание легких изотопов углерода $\left({ }^{12} \mathrm{C}\right)$. Геологи и ученые, изучающие атмосферу, пытаются установить его происхождение. Ни внезапное уничтожение жизни на Земле и последующий приток ${ }^{12} \mathrm{C}$ в океан, ни весь объем ${ }^{12} \mathrm{C}$, поступивший в атмосферу из $\mathrm{CO}_{2}$ в результате извержения Сибирских траппов, недостаточны для объяснения наблюдаемого сдвига. Кое-что еще необходимо для этого, и оно заключается в установлении поступления метана, выделенного из газовых гидратов [32, 34]. Есть предположение, что первоначальное глобальное потепление на границе перми и триаса было спровоцировано сибирскими извержениями, разогревшими замерзшие тела газовых гидратов, и большое количество метана (изобилующее ${ }^{12} \mathrm{C}$ ) достигало поверхности океана в виде громадных пузырей. Эта масса вводимого в атмосферу метана была причиной дальнейшего потепления, которое еще больше разогревало запасы газогидратов. Процесс продолжался по спирали с обратной связью, что привело к образованию «феномена неуправляемого парникового эффекта». Возможно, был достигнут критический порог, после которого естественные системы не могли управлять уровнем нормального редуцирования диоксида углерода. Нарастающий выход системы из под контроля привел к величайшему в истории Земли краху жизни.

Продолжительность кризиса достойна исследования. По данным флоры и фауны, мы можем видеть, что восстановление охватило длительное время. Действительно, сведения по изотопам углерода позволяют предположить, что кризисные условия должны были существовать до 5 млн лет, т.е. до раннего триаса. Авторы работы [34] в обзоре геохимических данных по всему миру отметили, что первоначальный сдвиг отрицательных углеродных изотопов на границе перми и триаса явился следствием трех или четырех последовательных отрицательных аномалий, близких по магнитуде, которые нивелировались к концу раннего триаса. Содержание углеродных изотопов понижается до уровня, предшествующего вымиранию, к середине анизия. По мнению авторов работы [34], этот пример длительной от- 
рицательной аномалии ${ }^{13} \mathrm{C}$ предполагает большой период воздействия причин ее образования, и что здесь могут быть либо океанические стратификационные смещения, либо реорганизация углеродного цикла.

Есть свидетельства предшествующего всемирного недостатка кислорода в раннем триасе, которые предполагают некоторое напластование (без смешения и окисления донных вод). Трудно показать оборот, когда время от времени смешиваются легкоизотопный органический материал из нижних вод с поверхностными водами.

Перестройка углеродных циклов предполагает, что захороненный на суше произведенный органический материал был подвержен сильному разрушению, это подтверждается массовой потерей растительности на границе перми и триаса вследствие кислотных дождей и аридизации климата и последующим «угольным провалом», когда отсутствовали леса и растительный материал не продуцировался и не захоронялся в нормальных количествах. Морской органический материал продуцирует более легкие изотопы углерода, чем наземный или смешанный. Существуют различия в содержании ${ }^{13} \mathrm{C}$ в 7-8\% между растворенным углеродом в море по сравнению с $\mathrm{CO}_{2}$ атмосферы.

Возможно, что кризис поствымирания можно разделить на 2 части. Первая - непосредственно после катастрофы, которая длилась, возможно, несколько тысяч лет, как и излияния сибирских траппов. Вторая, более длительная, возможно, заключала в себе все 5 млн лет или ранний триac, когда растения на суше были редки, леса не сформировались и тетраподовые сообщества состояли в основном из мало- и среднеразмерных животных, занимавших ограниченные ниши, не включавшие травоядных и хищников. Необходимы более точные данные по разрезам раннего триаса и детальное изучение фоссилий.

\section{Заключение}

При изучении массового вымирания пермотриаса много внимания уделялось морским разрезам. Их такое изучение должно быть продолжено для определения точности географической протяженности (размер, пределы) таких фаз массового вымирания и возрождения после вымирания. Мы считаем, что континентальные разрезы будут ценны. Они представляют важную часть биосферы и другую половину углеродного цикла. Классический обзор говорит о том, что континентальные разрезы очень тяжелы для датировки и они могут дать более скудную информацию о фаунистических и флористических изменениях. Мы считаем, что потенциал заключается в хорошем полном изучении. Необходимы создание независимых стратиграфических схем и детальное изучение седиментологии и сходных вопросов.
Если модель парникового эффекта уточнить, то можно будет объяснить величайший кризис на Земле за последние 500 млн лет. Эта модель имеет ценность для дальнейших исследований. Она представляет изображение глобального слома механизма регулирования окружающей среды, где нормальные системы стремились к уравновешиванию атмосферных газов и температуры на протяжении сотен тысяч лет, до вступления его в действие.

Модель древних событий вымирания воздействовала на нынешние споры о глобальном потеплении и дала возможность составления среднесрочных прогнозов. Некоторые ученые и политики видят опасность для человечества в приближении астероидов. Возможно, будет обращено внимание и на большое глобальное потепление, длительность которого введет в игру неудержимый парниковый эффект.

Я благодарен всем участникам наших экспедиций в России в прошлье года и особенно Ричарду Твитчетту за чтение этой статьи и внесение коррективов.

\section{Библиографический список}

1. Carroll R.L. Vertebrate paleontology and evolution H. Freeman. San Francisco, 1988.

2. Erwin D.H. The great Paleozoic crisis: Life and death in the Permian. Columbia University Press, N.Y., 1993.

3. Erwin D.H. The Permo-Triassic mass extinction// Nature. 1994. Vol. 367. P. 231-236.

4. Benton M.J. When life nearly died: the greatest mass extinction of all time. L., 2003.

5. Erwin D.H. Extinction: How life on Earth nearly ended 250 million years ago. Princeton University Press, Princeton, 2006.

6. Newell A.J., Gower D.J., Benton M.J., Tverdokhlebov V.P. Bedload abrasion and in situ fragmentation of bivalve shells // Sedimentology. 2007. Vol. 54. P. 835-845.

7. Benton M.J., Tverdokhlebov V.P., Surkov M.V. Ecosystem remodeling among vertebrates at the Permian-Triassic boundary in Russia // Nature. 2004. Vol. 432. P. 97-100.

8. Newell A.J., Tverdokhlebov V.P., Benton M.J. Interplay of tectonics and climate on a transverse fluvial system, Upper Permian, southern Uralian foreland basin // Sedimentary Geology. 1999. Vol. 127. P. 11-29.

9. Твердохлебов В.П. Общие черты палеогеографии юговостока Русской плиты и Предуралья // Изв. АН СССР. Сер. геол. 1971. Р. 110-115.

10. Ward P.D., Montgomery D.R., Smith R.H.M. Altered river morphology in South Africa related to the Permian-Triassic extinction // Science. 2000. Vol. 289. P. 1741-1743.

11. Michaelsen $P$. Mass extinction of peat-forming plants and the effect on fluvial styles across the Permian-Triassic boundary, Northern Bowen Basin, Australia // Palaeogeography, Palaeoclimatology, Palaeoecology. 2002. Vol. 179. P. 173-188. 12. Sarkar A., Yoshioka H., Ebihara M., Naraoka H. Geochemical and organic carbon isotope studies across the continental Permo-Triassic boundary of Raniganj Basin, eastern 
India // Palaeogeography, Palaeoclimatology, Palaeoecplpgy. 2003. Vol. 191. P. 1-14.

13. Arche A, Lopez-Gomez J. Sudden changes in fluvial style across the Permian-Triassic boundary in the eastern Iberian Ranges, Spain: Analysis of possible causes // Palaeogeography, Palaeoclimatology, Palaeoecology. 2005. Vol. 229. P. 104126.

14. Collinson J.W., Hammer W.R., Askin R.A., Elliot D.H. Permian-Triassic boundary in the central Transantarctic Mountains, Antarctica // Bull. of Geological Society of America. 2006. Vol. 118. P. 747-763.

15. Retallack G.J. Earliest Triassic claystone breccias and soil-erosion crisis // J. of Sedimentary Research. 2005. Vol. 75. P. 679-695.

16. Wignall P.B., Twitchett R.J. Oceanic anoxia and the end Permian mass extinction // Science. 1996. Vol. 272. P. 11551158.

17. Retallack G.J. Permian-Triassic life crisis on land // Science. 1995. Vol. 267. P. 77-80.

18. MacLeod K.G., Smith R.M.H., Koch P.L., Ward P.D. Timing of mammal-like reptile extinction across the PermianTriassic boundary in South Africa // Geology. 2000. Vol. 28, P. 227-230.

19. Tverdokhlebov V.P., Tverdokhlebova G.I., Benton M.J., Storrs G.W. First record of footprints of terrestrial vertebrates from the Upper Permian of the Cis-Urals, Russia // Palaeontology. 1997. Vol. 40. P. 157-166.

20. Губин Ю.М., Голубев В.К., Буланов В.В., Петухов С.В. Следы парейазавров из верхней перми Восточной Европы // Палеонтологический журн. 2003. Т. 37. С. 514-523.

21. Heyler D., Lessertisseur J. Pistes de tetrapodes Permiens de la region de Lodeve (Herault) // Memoire du Museum National d Histoire Naturelle, Paris. Serie C. Sciences de la Terre. 1963. Vol. 11. P. 125-221.

22. Tverdokhlebov V.P., Tverdokhlebova G.I., Minikh A.V. et al. Upper Permian vertebrates and their sedimentological context in the South Urals, Russia // Earth-Science Reviews. 2005. Vol. 69. P. 27-77.
23. Rubidge B.R. Biostratigraphy of the Beaufort Group (Karoo Supergroup) // Geological Survey of South Africa, Biostratigraphic Series. 1995. Vol. 1. P. 1-46.

24. Каландадзе Н.Н., Куркин А.А. Новый пермский дицинодонт и вопрос происхождения Kannemeyeroidea // Палеонтологический журнал. 2000. Т. 36. С. 642-649.

25. Kemp T.S. The origin and evolution of mammals. Oxford University Press, Oxford, 2005.

26. Surkov M.V., Benton M.J., Twitchett R.J.et al. The first occurrence of footprints of large therapsids from the Upper Permian of European Russia // Palaeontology. 2007. Vol. 50. P. 641-652.

27. Tverdokhlebov V.P., Tverdokhlebova G.I., Surkov M.V., Benton M.J. Tetrapod localities from the Triassic of SE of European Russia // Earth-Science Reviews. 2003. Vol. 60. P. 1-66.

28. Smith R.H.M., Botha J. The recovery of terrestrial vertebrate diversity in the South Africa Karoo Basin after the endPermian extinction // Comptes Rendus Palevol. 2005. Vol. 4. P. 623-636.

29. Surkov M.V., Kalandadze N.N., Benton M.J. Lystrosaurus georgi, a dicynodont from the Lower Triassic of Russia // J. of Vertebrate Paleontology. 2005. Vol. 25. P.402-413.

30. Battail B., Surkov M.V. Mammal-like reptiles from Russia / Eds. M. Benton, M. Shishkin, D. Unwin, E. Kurochkin. The age of Dinosaurus in Russia and Mongolia. Cambridge University Press, Cambridge, 2000. P. 86-119.

31. Grauvogel-Stamm L., Ash S.R. Recovery of the Triassic land flora from the end-Permian life crisis // Comptes Rendus Palevol. 2005. Vol. 4. P. 593-608.

32. Wignall P.B. Large igneous provinces and mass extinctions // Earth-Science Reviews. 2001. Vol. 53. P. 1-33.

33. Benton M.J., Twitchett R.J. How to kill (almost) all life: the end-Permian extinction event // Trends in Ecology and Evolution. 2004. Vol. 18. P. 358-365.

34. Corsetti E.A., Baud A., Marenco P.J., Richoz S. Summary of Early Triassic carbon isotope records // Comptes Rendus Palevol. 2005. Vol. 4. P. 405-418.

\section{ПАЛЕОГЕОГРАФИЧЕСКАЯ ИНТЕРПРЕТАЦИЯ ТАФОНОМИИ ОСНОВНЫХ МЕСТОНАХОЖДЕНИЙ ИХТИОФАУНЫ СРЕДНЕЙ И ВЕРХНЕЙ ПЕРМИ ЕВРОПЕЙСКОЙ РОССИИ}

\section{М.Г. Миних, А.В. Миних, Д.И. Янкевич 1 \\ Саратовский государственный университет, кафедра геоэкологии \\ E-mail: MinihMG@info.sgu.ru \\ 10тделение геологии НИИ ЕН СГУ}

Палеогеографические реконструкции обстановок осадконакопления в значительной мере детализированы тафономическими данными исследований местонахождений ихтиофауны, среди которых пермские рыбы Восточной Европы в последние годы приобрели статус ортостратиграфических. Проведенные тафономические исследования ряда местонахождений средне- и позднепермской ихтиофауны во многом подтверждают реальность существования в казанский, уржумский и северодвинский века на территории Европейской России довольно крупных бассейнов седиментации, имевших периодическую связь с Мировым океаном.

Ключевые слова: местонахождения ихтиофауны, средняя и верхняя пермь, европейская часть России, тафономия, палеогеографическая интерпретация. 